\title{
Prolonged endoscopic loop ligation for removal of gastrointestinal tumors
}

Endoscopic loop ligation has been shown to be successful in the removal of a variety of large mucosal and submucosal tumors of the gastrointestinal tract, such as lipomas, leiomyomas, lymphangiomas, carcinoid tumors, and Brunner's adenomas [1-4]. However, immediate release of the endoscopic loop after ligation of the tumor may fail to eradicate the lesion in one session $[1,2]$. We therefore evaluated the effect of holding on to the ligating loop for 15 minutes prior to its release on the rate of complete resection in one session, which therefore avoided a second session of loop ligation.

Four patients ( 3 men, 1 women; age range 51-74) underwent loop ligation of a pedunculated gastrointestinal tumor ( Table 1). A 30-mm diameter Olympus PolyLoop (Olympus Medical Systems Inc., Center Valley, Pennsylvania, USA) was placed around the stalk and tightened. The lesion was closely observed for evidence of change in color to the characteristic dusky hyperemic appearance of congested vascular mucosa.

In patient \#1, the loop was released immediately in the first procedure as described in the literature [5]. A repeat procedure was performed 3 months later to ligate the residual lipoma. Patients \#2 and \#3 underwent loop ligation of colonic pedunculated submucosal lipomas. In these patients tension was maintained on the loop for 15 minutes prior to its release ( $\odot$ Fig. 1; $\odot$ Video 1). Patient \#4 underwent loop ligation of a $3-4-\mathrm{cm}$ pedunculated adenoma with the loop again held for 15 minutes ( Fig. 2 ).

In our small series, endoscopic loop ligation with the loop being held for 15 minutes before release resulted in complete resection of all the lesions. Sustained tension on the endoscopic loop for the initial 15 minutes following ligation may be the optimal time to cause tissue ischemia and damage, which therefore allows complete resection of the lesion in one session. Prolonged endoscopic loop ligation eradicates pedunculated lipomas and adenomas without the need for cautery, thereby also limiting the risk of cautery-related perforation. Further studies are needed to confirm and standardize the techniques for endoscopic loop ligation in the man-
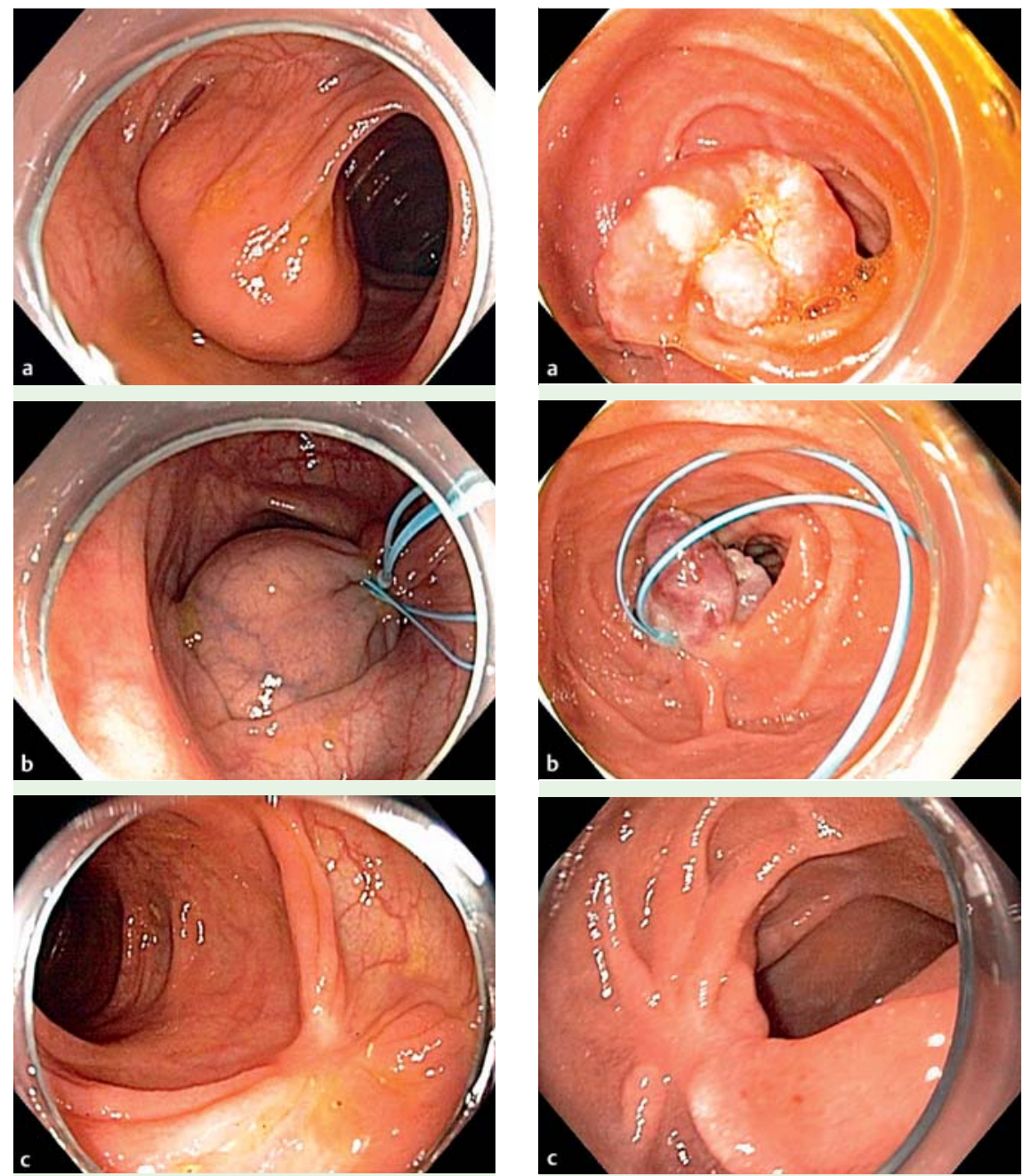

Fig. 1 Endoscopic loop ligation of a colonic lipoma showing: a the appearance of the colonic lipoma before treatment; $\mathbf{b}$ the ligation loop in position around the stalk of the colonic lipoma; $\mathbf{c}$ the scar resulting from autoamputation of the lipoma after endoscopic loop ligation.

agement of different types of gastrointestinal tumors.

Endoscopy_UCTN_Code_TTT_1AO_2AG

Competing interests: None

\section{Video 1}

Endoscopic loop ligation of a colonic lipoma with the loop being held under tension for a prolonged period of 15 minutes.

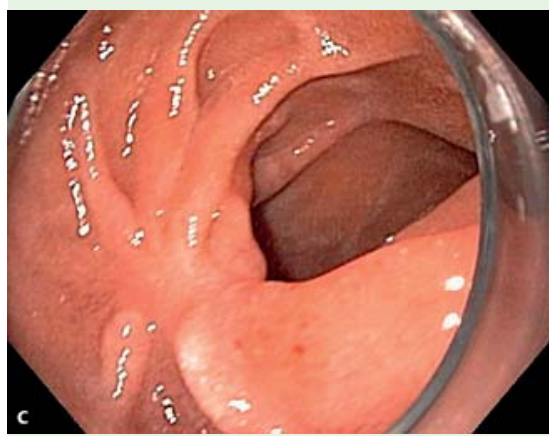

Fig.2 Endoscopic loop ligation of a duodenal adenoma showing: $\mathbf{a}$ The appearance of the duodenal adenoma before treatment; $\mathbf{b}$ the ligation loop in position around the base of the duodenal adenoma; $\mathbf{c}$ the scar resulting from autoamputation of the duodenal adenoma after endoscopic loop ligation.

W. C. Chen ${ }^{1}$, B. Weston ${ }^{2}$, S. G. Krishna ${ }^{2}$, G. Gomez ${ }^{3}$, A. Rashid², M. H. Katz ${ }^{2}$, J. E. Lee ${ }^{2}$, G. S. Raju ${ }^{2}$

${ }^{1}$ Department of Medicine, The Methodist Hospital, Weill Cornell Medical College, Houston, Texas, USA

2 The University of Texas MD Anderson Cancer Center, Houston, Texas, USA

${ }^{3}$ Department of Surgery, The University of Texas Medical Branch Galveston, Galveston, Texas, USA 
Table 1 Characteristics of the four patients with pedunculated tumors in the gastrointestinal tract who underwent endoscopic loop ligation with prolonged tension being maintained on the loop before release.

\begin{tabular}{|c|c|c|c|c|c|c|c|c|}
\hline $\begin{array}{l}\text { Patient } \\
\text { number }\end{array}$ & $\begin{array}{l}\text { Age, } \\
\text { years }\end{array}$ & Sex & Site & $\begin{array}{l}\text { Size, } \\
\mathrm{cm}\end{array}$ & Diagnosis & Ligation time & $\begin{array}{l}\text { Outcome } 3-6 \text { months } \\
\text { later }\end{array}$ & Follow-up \\
\hline$\# 1$ & 70 & Male & $\begin{array}{l}\text { Transverse } \\
\text { colon }\end{array}$ & $4-5$ & Lipoma & Seconds & Residual lipoma & $\begin{array}{l}\text { Repeat ligation at } 3 \text { months } \\
\text { with complete eradication } \\
\text { of the lesion }\end{array}$ \\
\hline$\# 2$ & 66 & Male & $\begin{array}{l}\text { Sigmoid } \\
\text { colon }\end{array}$ & 4 & Lipoma & 15 minutes & $\begin{array}{l}\text { Complete resection with } \\
\text { a well-healed scar }\end{array}$ & \\
\hline \#3 & 51 & Female & $\begin{array}{l}\text { Transverse } \\
\text { colon }\end{array}$ & $5-6$ & Lipoma & 15 minutes & $\begin{array}{l}\text { Complete resection with } \\
\text { a well-healed scar }\end{array}$ & \\
\hline$\# 4$ & 74 & Male & Duodenum & $3-4$ & Adenoma & 15 minutes & $\begin{array}{l}\text { Complete resection with } \\
\text { a well-healed scar plus flat } \\
\text { lesion distal to the scar }\end{array}$ & $\begin{array}{l}\text { Endoscopic mucosal resec- } \\
\text { tion of the flat lesion distal to } \\
\text { the lesion with complete era- } \\
\text { dication of the lesion }\end{array}$ \\
\hline
\end{tabular}

\section{References}

1 Raju GS, Gomez G. Endoloop ligation of a large colonic lipoma: a novel technique. Gastrointest Endosc 2005; 62: 988 - 990

2 Lee SH, Park JH, Park do $H$ et al. Endoloop ligation of large pedunculated submucosal tumors (with videos). Gastrointest Endosc 2008; 67: 556-560

3 Katsinelos P, Chatzimavroudis G, Zavos $C$ et al. Endoloop-assisted amputation of a large rectal lipoma. Gastrointest Endosc 2007 66: $636-637$

4 Veloso R, Pinho R, Rodrigues A et al. Endoloop ligation ("loop-and-let-go") of a large ilea lipoma by balloon-assisted enteroscopy. Endoscopy 2012; 44: E176

5 Waye JD. New methods of polypectomy. Gastrointest Endoscopy Clin N Am 1997; 7: $413-422$

\section{Bibliography}

DOI http://dx.doi.org/

10.1055/s-0032-1326075

Endoscopy 2013; 45: E69-E70

(C) Georg Thieme Verlag KC

Stuttgart · New York

ISSN 0013-726X

\section{Corresponding author}

\section{G. S. Raju, MD}

The University of Texas MD Anderson

Cancer Center

1515 Holcombe Blvd, Gl Division - Unit 1466

Houston, TX 77030-4009

USA

Fax: +1-713-694-5398

gsraju@mdanderson.org 